\begin{tabular}{c}
\hline Review of \\
ECONOMICS \\
and \\
INSTITUTIONS
\end{tabular}

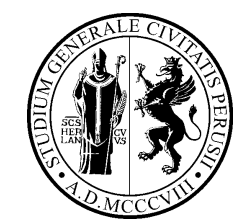

www.rei.unipg.it

\title{
Understanding R\&D Policy: Efficiency or Politics?
}

\author{
Fidel Perez-Sebastian ${ }^{\bowtie}$ \\ University of Alicante
}

\begin{abstract}
This paper searches for the determinants of government-funded R\&D. The goal is to disentangle whether the efficiency considerations overwhelmingly emphasized by the theoretical literature are indeed the main driving force behind public R\&D expenditures. Another goal of the paper is to assess whether other types of innovation policy such as the degree of patent protection have an impact on private R\&D. I find that there are important differences between rich and poor nations at this respect. In particular, market-failure factors do not have strong power to explain public R\&D in rich and middle-income nations, whereas related variables such as the access to private credit and knowledge spillovers are important in less developed economies. In rich countries, public innovation effort can be better explained by the political economy variables that determine the size of governments. Private R\&D, on the other hand, depends in high income economies on R\&D policies that try to improve R\&D efficiency, but is highly determined by government size in less income nations. Results suggest that more research on political economy theories of innovation might be important to understand R\&D investment, and that R\&D policy should be revised to relate it more closely to efficiency considerations.
\end{abstract}

JEL classification: O30; 038; O40

Keywords: R\&D, market failures, political factors, economic growth

I am grateful to Lola Collado and participants in the 2009 Symposium in Applied Economics at ETH Zurich for comments, and to the Spanish Ministry of Science and Innovation (SEJ2007-62656) and IVIE for financial support.

\footnotetext{
$\square$ Address: School of Economics, University of Alicante, Campus de San Vicente s/n, 03080 - Alicante, Spain. (Phone +34 9659036 14. Email: fidel@merlin.fae.ua.es).
}

\section{Recommended Citation}

Perez-Sebastian, F. (2012). Understanding R\&D Policy: Efficiency or Politics? Review of Economics and Institutions, 3(3), Article 2. doi: 10.5202/rei.v3i3.90. Retrieved from http://www.rei.unipg.it/rei/article/view/90 


\section{Introduction}

The seminal work of Robert Solow $(1956,1957$, and 1962) concluded that technological change is key to sustained economic growth. Over the years, the recognition of this fundamental result has pushed innovation to the forefront of the policy agenda. Innovation consists on the discovery of new products and processes, and requires R\&D investment in most instances. Governments, therefore, design policies to increase the amount of R\&D in the economy. One the one hand, policies such as anti-brain-drain measures, financial market reforms, improvement of the patent protection system, and tax relief, among others, try to incentive private R\&D. Government-funded $\mathrm{R} \& \mathrm{D}$, on the other, allocates resources directly to the inventive activity! 1

We could say that the theoretical literature explains R\&D policy based on efficiency considerations. There are many market failures related to R\&D investment. Following Arrow (1962) and Nelson (1959), the possible failure of perfect competition to achieve an optimal allocation of resources is a consequence of the increasing returns, inappropriability, and uncertainty that surround the invention process. Papers such as Romer (1990), Jones and Williams (2000), and Aghion and Howitt $(1992,2006)$ have analyzed in detail their consequences on the allocation of R\&D. Empirically, these market failures make that papers like Griliches (1992) and Jones and Williams (1998), among others, find evidence that the social return to R\&D is well above its private counterpart.

The last paragraph implies that we already know quite a bit about the normative side of Government funded R\&D. But what about the positive side? There is no paper in the literature that tries to disentangle the forces that determine R\&D policy in reality $\left.\right|^{2}$ This is an important gap because efficiency considerations are not the only potential determinant of government's policy. There is an important literature on the political economy of the size of governments (see below), which suggests that public intervention in $R \& D$ could be also a consequence of political pressure. If the last force ends up being important, it should lead the theoretical literature to seriously think of introducing it into our models of R\&D, and policymakers to rebuild innovation policy more closely linked to efficiency considerations.

This paper sheds light on this issue. More specifically, I address the fol-

1 An example of the importance of R\&D policy is given by the European Union (EU) objectives of the 2002 Barcelona Council: Increasing R\&D in the EU from 1.9\% to 3\% of GDP by 2010 to become one of the most competitive and dynamic knowledge based economy in the world, capable of sustainable economic growth with more and better jobs and greater social cohesion.

2 Within the literature that tries to test whether public R\&D complements or crows out private $R \& D$, there are some papers that estimate reduced form equations for governmentfunded R\&D using firm- and industry-level data; see David et al. (2000) for a review. The goal of these equations is, however, generating predicted values for public R\&D that can be used as an instrument in the private R\&D expression. 
lowing questions. What are the determinants of government-funded R\&D? Which theory receives more support? Does private R\&D respond to innovation policy in the expected direction? In addition, given that most empirical papers at the aggregate level focus on total R\&D but private and public R\&D can respond differently to incentives, another contribution of the paper is studying whether previous results hold when we split both components.

The key finding is that the answer to those questions is different for different country groups. More specifically, public R\&D is mainly related to political factors such as budgetary pressure, political rights, government size and Wagner's law in rich nations. In less developed countries, however, public R\&D is associated to the size of the economy and the size of the government, but also to efficiency considerations such as the relative lack of private credit and knowledge spillovers. Private R\&D, on the other hand, is in rich nations mainly a response to efficiency variables that include market size, access to credit, patent protection, and distance to the frontier. In developing countries, private innovation effort is highly determined by the size of the public sector; thus suggesting that the public sector in those economies is required to build the knowledge, human and physical capital bases necessary for successful R\&D effort.

I proceed as follows. The next section briefly revises $R \& D$ data across nations. Section 3 introduces, again briefly, a well known model of optimal $R \& D$ investment, and discusses different theories of $R \& D$ and the size of governments. Section 4 describes the empirical model, the data employed in the estimation exercise, and the econometric methodology. Results are presented in section 5. Section 6 concludes.

\section{R\&D Data across Nations}

R\&D investment, both at the public and private levels, differs substantially across nations. Figure 1 shows 5-year averages for the period 19812005 for a sample of 44 nations against their level of income. $3^{3}$ We see that both private and public $R \& D$ display positive trends. That is, economies, on average, allocate more and more resources to the inventive activity as they become richer. However, the cloud of points for private R\&D highlights a steeper trend and is more heteroskedastic and dispersed. For example, the slope coefficient of the straight line that better fits the data is $6 E-05$ and the coefficient of variation is 0.86 for this variable, whereas the same numbers become $2 E-05$ and 0.54 for the public R\&D cloud. For low levels of develop-

3 These nations are Argentina, Australia, Austria, Belgium, Bolivia, Brazil, Canada, Chile, Cyprus, Denmark, Ecuador, Finland, France, Germany, Greece, Hungary, Iceland, India, Ireland, Israel, Italy, Japan, Malaysia, Mauritius, Mexico, Netherlands, New Zealand, Norway, Pakistan, Panama, Portugal, Singapore, South Africa, South Korea, Spain, Sweden, Switzerland, Thailand, Tunisia, Turkey, Uganda, United Kingdom, United States, and Venezuela. 
ment, the government is the main source of $R \& D$ funds. Private financing becomes relatively more important as income per capita rises.

Figure 1 - R\&D as Percentage of GDP, 5-year Averages, 1981-2005, 44 Nations

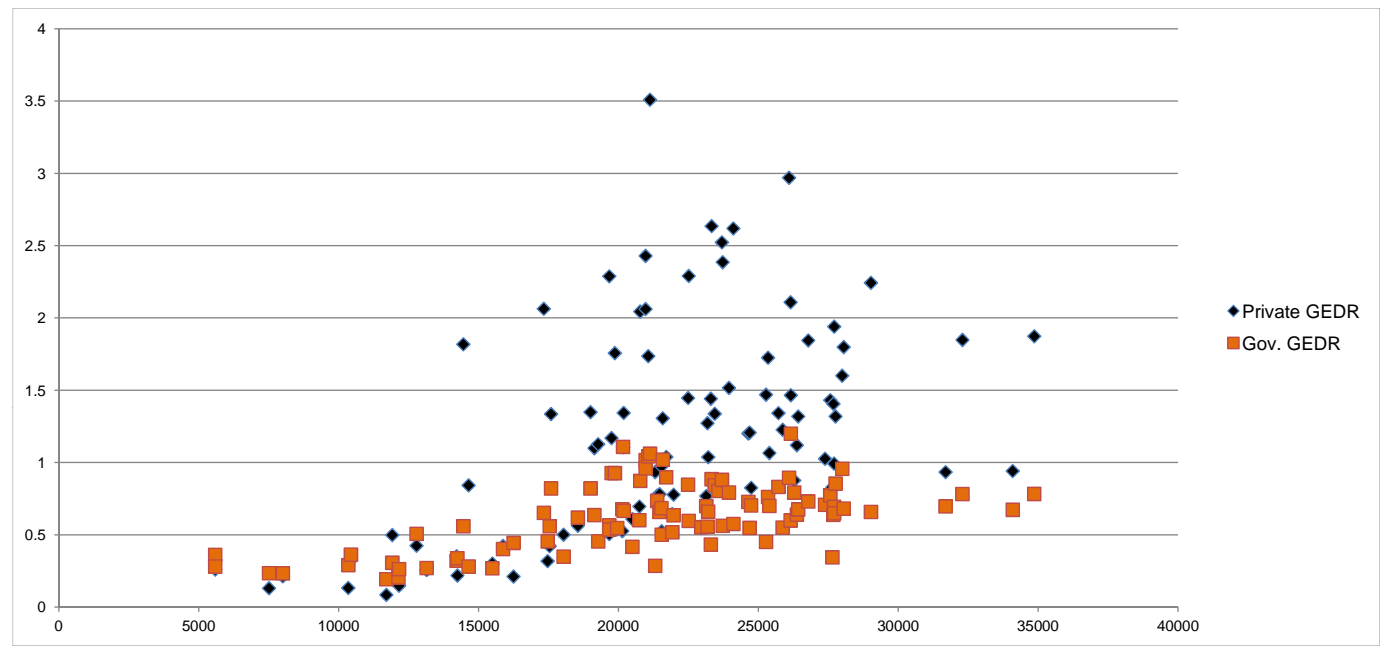

The same patters are obtained if we look at particular nations. Figure 2 shows R\&D data for a set of OECD and middle income nations. Rich countries, the ones that are closer to the technology frontier, are usually the economies that invest more in R\&D. In Figure 2, countries that invest at least $2.5 \%$ of GDP include only Finland, Israel, Japan, S. Korea, Sweden, Switzerland, and the USA. South Korea and Israel belong to the set of emerging economies that are making a big effort in $R \& D$. Singapore is another example of these emerging economies. We can see in the figure that Singapore allocated to invention and innovation a larger fraction of its GDP than richer economies like Italy and Spain.

Latin American nations are on the other side of the spectrum presented in Figure 2. They invest a relatively small fraction in R\&D. Argentina and Mexico show the lowest private investment (0.13) and public investment (0.23), respectively. If we sum up both components, the minimum total R\&D investment is the $0.42 \%$ of Argentina, compared to the maximum of $4.6 \%$ of Israel. There are clearly other nations in the world that invest even less in R\&D. For example, in our original 44 country sample, the economies that show the lowest average R\&D shares (close to 0.28\%) for the 2001-2005 interval are Pakistan, Bolivia, and Uganda.

\section{R\&D Theories}

There are several theories that highlight possible determinants of invention effort and could help explain the above general patterns. If we focus on public R\&D, they emphasize market-failures. The special nature of ideas implies that several market failures surround their production. Ideas are 
Figure 2 - R\&D as Percentage of GDP, Average for 2001-2005

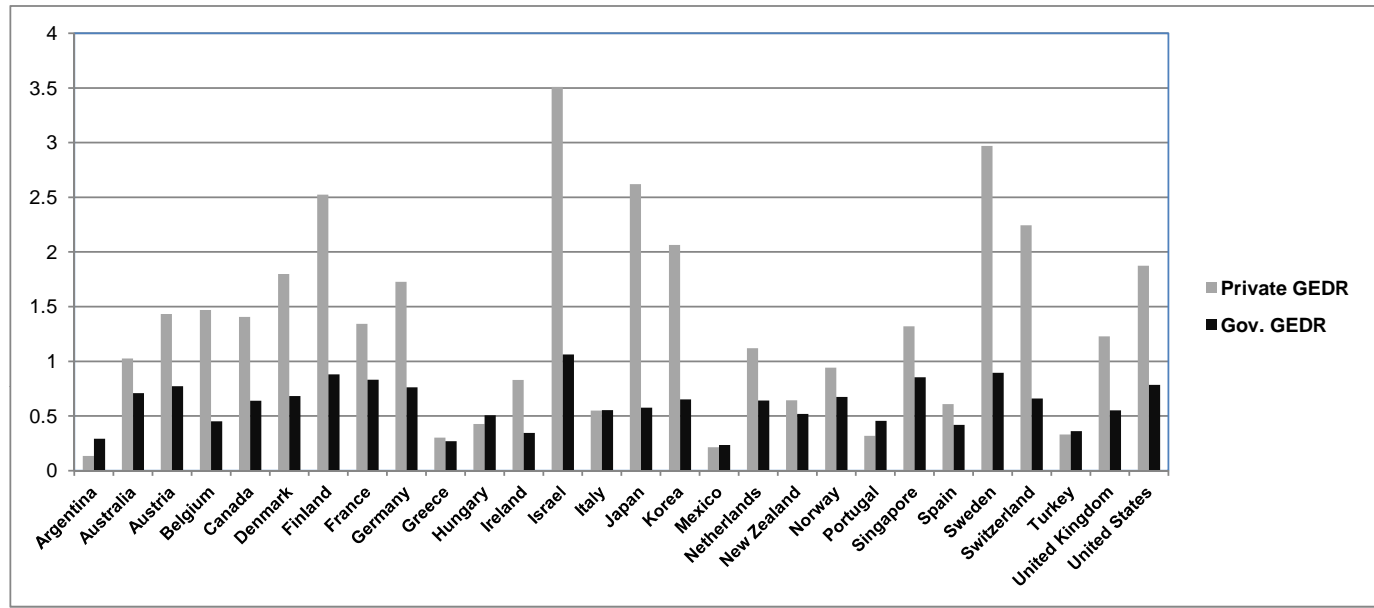

non-rivalrous and, therefore, their production generates important externalities. Among them, knowledge spillovers across firms (Howitt, 1999) and time (Romer, 1990) generate positive effects on the social value of R\&D. On the other hand, profit stealing coming from new products on old vintages, that is, the Schumpeter's (1942) creative destruction impact formalized by Aghion and Howitt (1992), and duplication of R\&D effort across independent firms represent negative externalities. Another negative externality is present in contexts where the adoption of foreign technology is important. R\&D directed to adapt technology to local conditions can suffer from diminishing imitation opportunities (Barro and Sala-i-Martin, 1997).

As an example to illustrate these market failures, consider an economy similar to the one in Romer (1990). The economy is populated by utilitymaximizing infinitely-lived consumers endowed with one unit of labor that they supply each period inelastically. There are three types of activities: consumption goods production, intermediate goods manufacturing, and R\&D investment. The latter is intended to learn new designs for new types of producer durables, being the source of technological progress. When a new design is learned, an intermediate goods producer acquires the perpetual patent over the design that allows monopoly pricing. The other two sectors obey perfect competition.

The final goods sector produces a homogeneous output $Y$ employing a variety of intermediate capital goods $x_{i}$ and labor $L$ according to the CES technology

$$
Y=L^{\alpha}\left[\int_{0}^{A} x_{i}^{(1-\alpha) \gamma} d i\right]^{\frac{1}{\gamma}} \quad 0<\alpha<1, \quad \gamma>0 .
$$

If $\gamma<1$, intermediate goods are complementary; they are substitutes if $\gamma>$ 1. This function displays constant returns to scale over capital and labor inputs. 
The economy increases the mass of producer durables types that can be used, $A$, either by inventing new designs or by imitating them from a country-specific international pool of ideas $A^{w}$ whose size increases exogenously at rate $g_{A^{w}}$. The increase in the total amount of producer durables varieties used in production at a given point in time $t$ is given by the following aggregate R\&D technology:

$$
(1+\psi) \dot{A}=\mu A^{\phi}\left[R_{I}^{\lambda}+\left(\frac{A^{w}}{A}\right)^{\beta} R_{C}^{\lambda}\right] \quad \lambda \in(0,1) ; \beta, \psi>0 ; A \leq A^{w}
$$

where $A^{w}$ is the worldwide stock of all ideas that can be used in production if they are learned, regardless of where they originated; and $R_{I}$ and $R_{C}$ are the amounts of output that the economy invests in R\&D related to innovation and imitation, respectively. This R\&D technology follows Jones and Williams $(1998,2000)$ and Barro and Sala-i-Martin (1997).

In equation (2), $\phi$ weights a knowledge spillover effect from learning new designs today to future learning productivity. This effect can be positive or negative depending on whether the parameter is larger or smaller than zero, respectively. The parameter $\lambda$ controls for the fact that two or more researchers can come up with the same idea either by chance or because of $\mathrm{R} \& \mathrm{D}$ races. Since $0<\lambda<1$, a congestion externality or, in other words, duplication of effort is present. The ratio $A^{w} / A$ incorporates an advantage of backwardness similar to the one in Parente and Prescott (1994) and in Barro and Sala-i-Martin $(1995,1997)$, implying that the cost of imitating foreign designs decreases as the worldwide stock gets relatively larger. Since $A$ is in the denominator, the imitation technology displays diminishing imitation opportunities, which cause a negative externality: higher levels of R\&D effort today may decrease the relative size of the international pool of ideas, thus making copying more costly in the future. The parameter $\psi$ captures a creative destruction effect, and follows Jones and Williams (2000). It is assumed that firms have to adopt new technology in packages composed of these $1+\psi$ designs. Only one of those designs is really new, whereas the other $\psi$ represent upgrades that replace the same number of existing $A$ types of durables goods.

It is well known that (for $\psi$ sufficiently small) the markup $\eta$ charged by intermediate-goods producers will be determined by the elasticity of substitution, $\eta=1 /[\gamma(1-\alpha)]$. It is also well known that production function (1) takes on the Cobb-Douglas form $Y=A^{\xi} L^{\alpha} K^{1-\alpha}$ at the aggregate level; where $K=\int_{0}^{A} x_{i} d i$ is the country's stock of physical capital, and $\xi=\frac{1}{\gamma}-(1-\alpha)$.

Define $g_{A}$ and $r$ as the rate of change of parameter $A$ and the interest rate, respectively. Standard methods allow obtaining the optimal steadystate allocation to R\&D as a fraction of final output $\left(S_{R}\right)$ delivered by the 
social-planner $(s p)$ and decentralized-economy $(d e)$ solutions: ${ }^{4}$

$$
S_{R}^{s p}=\frac{\lambda \xi g_{A}}{r-\left(g_{Y}-g_{A}\right)-g_{A}\left[\phi-\beta \frac{\left(A^{w} / A\right)^{\beta / 1-\lambda}}{1+\left(A^{w} / A\right)^{\beta / 1-\lambda}}\right]},
$$

and

$$
S_{R}^{d e}=\frac{\frac{\eta-1}{\eta}(1-\alpha)(1+\psi) g_{A}}{r-\left(g_{Y}-g_{A}\right)+\psi g_{A}} .
$$

Expressions (3) and (4) summarize the influence of market failures associated with the non-rivalrous nature of ideas on the R\&D decision. Unlike the social planner, firms do not take into account the existence of diminishing returns in learning due to duplication of effort. They equate marginal costs to average, instead of marginal, R\&D productivity. As a consequence, $S_{R}^{s p}$ increases with parameter $\lambda$, but $S_{R}^{d e}$ does not. The markup induced by monopoly pricing is irrelevant in the central planner's solution, but raises the decentralized economy's R\&D investment. The terms $\xi, \phi$, and $\beta\left(A^{w} / A\right)^{\beta / 1-\lambda} /\left[1+\left(A^{w} / A\right)^{\beta / 1-\lambda}\right]$ capture the effect of current R\&D on future final-output and R\&D productivities, which the decentralized economy does not internalize. The third term, in particular, represents the negative externality caused by diminishing imitation opportunities. As we see, this last external effect pushes up $S_{R}^{s p}$ as the economy approaches the technology frontier. The creative-destruction parameter $\psi$, on the other hand, is irrelevant for the social planner. It appears twice in equation (4). In the numerator because more designs allow for higher profits, and in the denominator because a larger probability of patent destruction diminishes the market value of patents. The net influence of $\psi$ on $S_{R}^{d e}$ is positive as long as the interest rate is larger than the growth rate of the economy.

The difference between $S_{R}^{s p}$ and $S_{R}^{d e}$ gives the public R\&D investment, as a fraction of GDP, necessary to achieve the first best. As we can see, its amount depends on two main variables: relative total factor productivity (TFP), captured above by $A^{w} / A$; and the growth rate of the productivity parameter, $g_{A}$, that weights the incidence of all externalities because they depend on future investment. As $A^{w} / A$ decreases, the social-optimum share of $R \& D$ rises, whereas the private one is not affected. This suggest that public R\&D effort should decrease with $A^{w} / A$. The effect of changes in $g_{A}$ is, on the other hand, ambiguous, and depends on the strength of the different externalities. All this will prove useful later on when the econometric model is specified.

Besides the ones related to non-rivalness, there exist other market failures due to credit rationing (Hall, 2005) and partial excludability of ideas (Romer, 1990). Both of them produce underinvestment in R\&D. If R\&D needs external financing, the market will not finance all projects that are

\footnotetext{
${ }^{4}$ See the appendix for details.
} 
socially profitable. The problem is amplified by the uncertainly of invention if investors can not buy protection against it (Arrow, 1962). This last effect diminishes as financial markets develop. Solving the partial excludability problem, on the other hand, requires the design of effective property rights such as a patent system.

So far, I have taken into account only efficiency considerations. The design of policy can be, however, a consequence of political pressure. There is an important literature on the political economy of the size of governments that tries to explain the flow of resources generated by the public sector (e.g., see Drazen, 2000), and government-funded R\&D can be considered simply part of this flow. Probably, the most basic political theory of government intervention is the Wagner's hypothesis. Adolph Wagner (1967) defended that the public sector share in GDP will grow continually as nations industrialize. Wagner provided several reasons for this observation. First, as national income increases, industrialization and urbanization generates additional needs for government services beyond the traditional national defence and legal system, like cultural and welfare expenditures. Second, government spending may increase in activities that complement the private sector funding for long-term investments related to economic development and changes in technology.

Other authors argue that the degree of political rights is an important determinant of the size of the public sector. Meltzer and Richard (1981), in particular, offer a theory that implies that extensions of the franchise increase the public sector size, measured as the share of income redistributed in cash or in services. Increasing openness can also be a source of public demand for government intervention. It is clear, for example, that the sophistication of nations like China, South Korea, or Taiwan have raised concerns about the future international competitiveness of firms and job losses in certain industries; thus increasing social demands for government intervention. At this respect, R\&D investment is perceived as a way to avoid this problem (Fagerberg, 1988). Openness, however, can also increase budgetary pressure and makes more difficult finance subsidies (e.g., see Schulze and Ursprung, 1999 for a review of the literature) ${ }^{5}$

Several of these variables can also affect private R\&D investment. Financial depth mitigates the uncertainty and fund availability problems contributing to more invention investment. A more developed patent protection system raises private expected profits, although its impact on R\&D is not clear (Howitt, 2004). Openness can increase incentives to invest in R\&D due to a larger market size, higher competition levels, and a larger flow

\footnotetext{
${ }^{5}$ Empirically, Easterly and Rebelo (1993) find that democracy does not matter but Wagner's law does for explaining the share of government revenue on GDP. Some papers on the Political Sciences literature such as Avelino et al. (2005) find positive association of some non-R\&D-related components of government spending with democracy. Regarding tests of the effect of openness on government expenditures, the main message is that there is no robust impact (see Dreher et al., 2008 for a recent contribution).
} 
of knowledge (e.g., Rivera-Batiz and Romer, 1991). Finally, a more stable political environment may generate higher expected returns to a long-run activity such as R\&D.

Empirically, some of these variables that can affect R\&D have received support. For example, Coe and Helpman (1995) and Eaton and Kortum (1996), Lederman and Maloney (2003), and Acemoglu and Linn (2004) find that the flow of ideas, financial depth, and market size matter positively for innovation, respectively. Varsakelis (2001) estimates that the degree of patent protection encourages R\&D investment, although openness does not matter. Aghion et al. (2005) estimate that the degree of market competition has an inverted U-shaped effect on innovation. Varsakelis (2006) using patent counts finds that political rights affect positively innovation output.

\section{The Model, Data, and Estimation Method}

I estimate the following R\&D regression:

$$
R \& D_{i t}=\gamma_{0}+\gamma_{1} \text { Dummies }_{i}+\gamma_{2} \text { Controls }_{i t-5}+\gamma_{3} \text { Focus }_{i t-5}+\varepsilon_{i t} .
$$

Regression (5) searches for the determinants of R\&D. The main goal behind this empirical exercise is to test which of the theories described in the previous section receives support in the data. Proxies for those theories are the ones called Focus variables. Controls represent other variables that can have an impact on R\&D investment. Finally, I add Dummies that try to capture country fixed effects to mitigate a potential omitted variable bias. Each variable is indexed by country $i$ and time $t$.

The dependent variable is R\&D as a fraction of GDP. We use three different R\&D measures: government-funded $R \& D$, private $R \& D$, and total R\&D. The first two measures are employed to search for its determinants. The third one is mainly considered for comparison. Missing observations were interpolated. I employ two different data sources. The first one is the OECD Main Science and Technology Indicators (S\&T), which provides figures from 1981 for OECD nations and a set of non-OECD members such as Argentina, Israel, and Singapore. The second one is UNESCO.

Dummies are of two types: regional, and legal origin. More specifically, I consider Middle East region, East Asian region, Latin America region, German legal origin, French legal origin, and UK legal origin. Gallup et al. (1999) and La Porta et al. (2008), among many others, argue that these types of variables have power to predict economic performance. They have the ability to capture a variety of country-specific fixed effects related to religion, culture, climate, and the regulatory and institutional environments. A dummy variable that controls for the R\&D data source is also added.

Proxies for market-failure considerations in government intervention are: relative TFP, the growth rate of TFP, credit to private sector, and patent protection. As argued above, the technology gap, measured as $A^{w} / A$, can affect 
negatively the socially-optimal allocation to the adaptation of innovations to local conditions. Expressions (3) and (4) suggest as well the introduction of the TFP growth rate, because it weights the incidence of non-rilvalnessrelated externalities. Assuming that relative TFP captures well the negative external effect associate with it, the estimated coefficient on TFP growth should tell us whether government-funded R\&D is affected by other market failures. In particular, a positive sign would say that knowledge spillovers are behind public R\&D, whereas creative destruction and duplication of effort would be behind a negative sign. Notice that these two variables can also affect private R\&D. Closeness to the technology frontier can favor the discovery of new inventions. TFP growth, on the other hand, is related to the impact of creative destruction on the market value of patents (see eq. 4).

In terms of measurement, TFP is computed relative to the U.S.. More specifically, for country $i$, its relative TFP equals $A^{i} / A^{U S}$. Notice that this is the inverse of the ratio $A^{w} / A$ employed above in the model, and needs to be taken into account when interpreting the estimated coefficients. If governments follow closely the advise of the market-failure literature, we will expect a positive estimated sign related to our measure of relative TFP in the public R\&D regression. A country's technology level is calculated as the residual not explained by physical capital and labor in a Cobb-Douglas aggregate production specification. Capital stocks are built employing investment rates from Penn World Tables 6.2 (PWT) and the perpetual inventory approach. The elasticity of capital is taken to be $1 / 3$. Relative TFP can also affect the private $\mathrm{R} \& \mathrm{D}$ decision.

To see if credit rationing matters in the private and government $R \& D$ decisions, the regressions incorporate total credit by deposit money banks and other financial institutions to the private sector as percentage of GDP from the 2007 update of Beck et al. (2000). To proxy for inventor's appropriability issues, I include Park's (2008) patent protection index. This is an update of Ginarte and Park's (1997). These authors construct a patent rights index using a coding scheme applied to national patent laws. They examined the following categories: (1) extent of coverage, (2) membership in international patent agreements, (3) provisions for loss of protection, (4) enforcement mechanisms, and (5) duration of protection. With this information, they offer an index that ranges from 0 to 5 with the higher values indicating stronger levels of protection. The theory suggests that the estimated coefficients related to the last two variables should be positive for private R\&D but negative for public R\&D, except for patenting that does not have a clear effect on private innovation effort.

Four variables also act as a proxy for political factors: political rights, GDP per capita, size of government, and openness. Political rights data try to test whether voting rights matter, as suggested by Meltzer and Richard (1981), and are provided by Freedom House. Freedom House constructs a discrete index that ranges from 1 to 7 . Countries that receive a lower rating 
are those with less corrupt and more stable governments, a larger degree of freedom and fairness in elections, with an opposition that plays a more significant role in the political system, and citizens that enjoy more selfdetermination. Because of that, a negative estimated coefficient will imply a positive effect of political rights. We expect exactly that in all R\&D regressions.

To test the Wagner's hypothesis, I use the level of GDP per capita and the government share in GDP, both from PWT. With this, I want to see whether R\&D investment follows other types of government spending or, put differently, whether is just a consequence of the government's willingness and capacity to mobilize resources $\sqrt{6}$ A positive impact of these two variables in the government-financed $R \& D$ regression will give support to the hypothesis. Finally, openness can capture political pressure from agents that see their revenues threaten, but also budgetary and competitive-environment considerations. Its estimated coefficient, according to the theory, should be positive for private innovation, but can have any sign for public R\&D. As a measure of openness, I employ imports plus exports as a fraction of GDP from WPT.

The control variables included are average years of schooling and population. Schooling and population are variables that can have a positive impact on the productivity of R\&D - the former one weighs the efficiency of the labor input, whereas the latter affects the size of the domestic market. Educational attainment comes from Barro and Lee (2001), and is the sum of the average number of years of primary, secondary and tertiary education in total population aged 15 and over. Total population is in thousands of inhabitants and is uploaded from PWT.

Data are averaged over 5 years for the intervals 1981-85, 1986-90, 199195, 1996-00, and 2001-05 to abstract from business-cycle influences, and alleviate potential measurement problems. For the schooling variable and the patent protection index that supply only one observation every five years, in 1980, 1985, ..., 2000, I use the year within the interval. After excluding nations that do not offer data for all variables (i.e., big oil producers, excommunist nations, and small economies like Iceland and Cyprus), I end up with an unbalanced panel with 38 nations and 146 observations..$^{7}$ The scale of variables is chosen to facilitate the interpretation of estimated coefficients. In particular, shares of output and growth rates are included in percentage terms, other continuous variables are taken in logs, discrete variables - the dummies and the political-rights index - are not modified.

${ }_{6}$ According to results in La Porta et al. (1999), the size of government could also proxy its quality.

7 The nations are the ones in footnote 3 excluding Cyprus, Ecuador, Hungary, Iceland, Mauritius, and Uganda. 


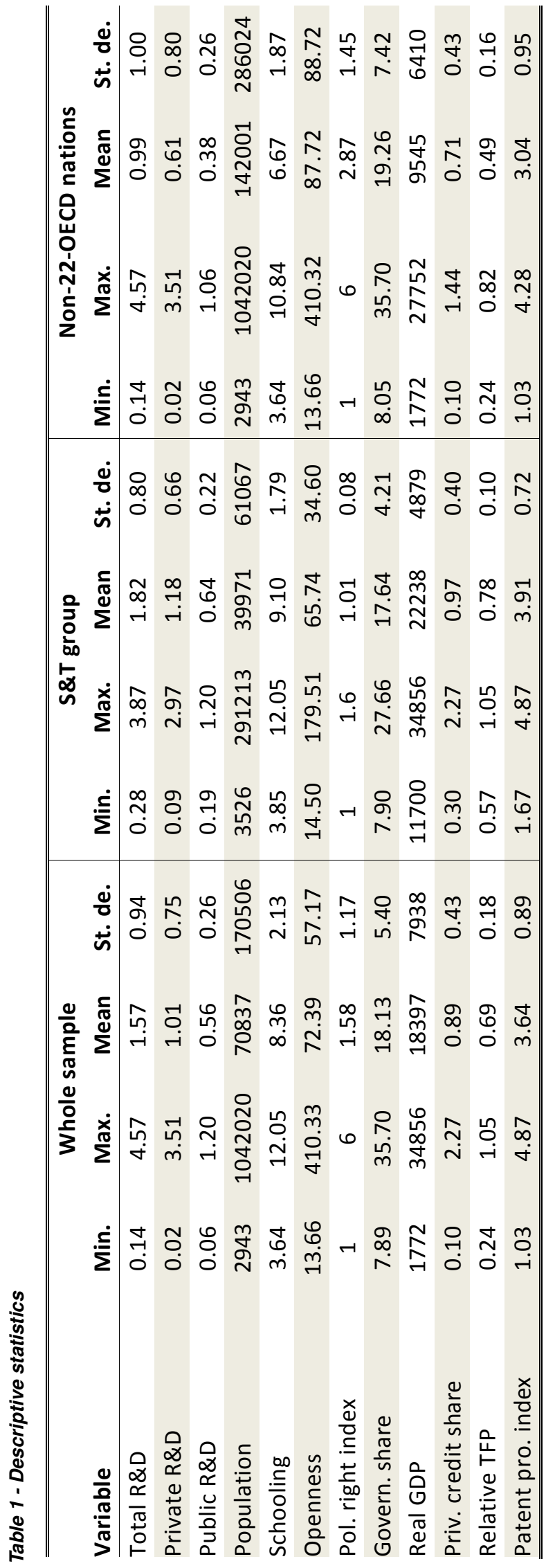


Endogeneity, and common latent variables that determine jointly the dependent and explanatory variables can be a source of bias. For example, both forms of R\&D and the patent system can respond to variations in the existing technological opportunities. To try to minimize this potential problem, I use first lags of the 5-year-averaged explanatory variables as regressors.$^{8}$ Given this, the number of data points available for the estimation exercise reduces to 119. Descriptive statistics of the different variables are offered in Table 1.

\section{Results}

Estimation is carried out separately for the whole sample, the S\&T sample, and excluding the 22-OECD economies. The S\&T group is composed of 27 rich and middle income economies. The non-22-OECD set includes the 17 poorest economies in the original sample..$^{9}$ OLS estimated coefficients are in Tables 2, 3, and 4. Regressions are estimated both excluding and including GDP per capita as explanatory variable. This exercise will help disentangle whether some variables show power just because there are correlated with GDP, which is important as the Wagner's hypothesis establishes that GDP per capita is one of the main determinants of the public-expenditure share. The tables also report White-heteroskedasticity-corrected standard errors in parentheses. The last rows indicate that all regressions are able to explain a large fraction of the variance of the dependent variables; in particular, around $80 \%$ for total and private $R \& D$, and $70 \%$ for public R\&D.

Table 2 reports the results for total R\&D. Let first focus on columns (1), (3), and (5) where GDP is not in the regression. Schooling, government spending, and relative TFP appear significant in all samples and, except for schooling in the non-22-OECD group, with strong positive sign. Population and the patent index also show positive power with the exception of the same country group. This is true as well for openness, with the exception of the whole sample. Private credit is important, with a positive sign, only in the set of rich and middle income economies. Finally, political rights and TFP growth show no explanatory power. Results when log GDP is included remain the same, except for the non-22-OECD sample in which the TFP coefficient is no longer significant and credit becomes weakly significant showing a negative sign.

The picture is, however, different when more disaggregated data are

8 Because private and public R\&D most likely suffer severely from these simultaneity problems, I do not include public R\&D as a regressor when private R\&D is the dependent variable, even though the literature has found that it is an important determinant (e.g., see David et al., 2000).

9 The 22 OECD group is the one first considered by Mankiw et al. (1992). The S\&T sample adds to those (excluding Iceland) Turkey, Israel, Singapore, South Korea, Mexico, and Argentina. Actually, the S\&T economies are the ones listed in Figure 2. Estimation on the 22-OECD sample added no new results. 
Table 2 - Regression results for the total R\&D share in GDP

\begin{tabular}{|c|c|c|c|c|c|c|}
\hline \multirow{2}{*}{ Variables } & \multicolumn{2}{|c|}{ Whole sample } & \multicolumn{2}{|c|}{ S\&T group } & \multicolumn{2}{|c|}{ Excluding 22-OECD } \\
\hline & (1) & (2) & (3) & (4) & (5) & (6) \\
\hline \multirow[t]{2}{*}{$\ln (\mathrm{Popu})$} & $0.164 * * *$ & $0.164 * * *$ & $0.143^{* * *}$ & $0.145^{* * *}$ & -0.060 & $-0.153 *$ \\
\hline & (0.039) & (0.039) & $(0.038)$ & $(0.038)$ & $(0.094)$ & $(0.082)$ \\
\hline \multirow[t]{2}{*}{$\ln ($ School) } & $0.724 * * *$ & $0.721 * * *$ & $0.543 * * *$ & $0.526 * * *$ & $-1.282 * *$ & $-2.282 * * *$ \\
\hline & $(0.184)$ & (0.195) & $(0.183)$ & $(0.185)$ & $(0.450)$ & $(0.432)$ \\
\hline \multirow[t]{2}{*}{ Open } & 0.001 & 0.001 & $0.001 * *$ & $0.001 * *$ & $0.002 * *$ & $0.002 * *$ \\
\hline & $(0.000)$ & $(0.001)$ & $(0.001)$ & $(0.001)$ & $(0.001)$ & $(0.001)$ \\
\hline \multirow[t]{2}{*}{ Poli. Rights } & 0.017 & 0.017 & -0.014 & -0.012 & -0.038 & -0.027 \\
\hline & $(0.027)$ & $(0.028)$ & $(0.043)$ & $(0.042)$ & $(0.026)$ & $(0.022)$ \\
\hline \multirow[t]{2}{*}{ Gov.Sr. } & $0.019 * "$ & $0.019 * "$ & $0.015^{* * *}$ & $0.016 * * *$ & $0.037^{* * *}$ & $0.050 * * *$ \\
\hline & $(0.003)$ & $(0.003)$ & $(0.004)$ & $(0.004)$ & $(0.006)$ & $(0.007)$ \\
\hline \multirow[t]{2}{*}{$\ln (R G D P p)$} & --- & 0.015 & --- & 0.179 & --- & $1.407 * * *$ \\
\hline & & $(0.283)$ & & $(0.186)$ & & $(0.337)$ \\
\hline \multirow[t]{2}{*}{ Credit } & 0.052 & 0.051 & $0.087^{\prime \prime}$ & $0.075 * *$ & -0.044 & $-0.193^{*}$ \\
\hline & $(0.035)$ & $(0.040)$ & $(0.035)$ & $(0.036)$ & $(0.126)$ & $(0.103)$ \\
\hline \multirow[t]{2}{*}{ In(Patent I.) } & $0.388 * *$ & $0.385 * *$ & $0.486 * * *$ & $0.423 * *$ & 0.156 & 0.072 \\
\hline & $(0.185)$ & $(0.192)$ & $(0.167)$ & $(0.172)$ & $(0.229)$ & $(0.274)$ \\
\hline \multirow[t]{2}{*}{$\ln ($ Re.TFP) } & $0.726 * * *$ & $0.710 * *$ & $0.965 * * *$ & $0.775 * *$ & $0.956 * * *$ & -0.567 \\
\hline & $(0.186)$ & $(0.192)$ & $(0.281)$ & $(0.349)$ & $(0.351)$ & $(0.506)$ \\
\hline \multirow[t]{2}{*}{ TFP growth } & 0.018 & 0.018 & -0.002 & -0.002 & 0.009 & 0.001 \\
\hline & $(0.011)$ & $(0.011)$ & $(0.012)$ & $(0.012)$ & $(0.017)$ & $(0.013)$ \\
\hline Observ. & 119 & 119 & 94 & 94 & 36 & 36 \\
\hline $\mathrm{R}^{2}$ & 0.813 & 0.813 & 0.854 & 0.855 & 0.844 & 0.899 \\
\hline $\bar{R}^{2}$ & 0.784 & 0.782 & 0.826 & 0.825 & 0.727 & 0.813 \\
\hline
\end{tabular}

Notes: * Significant at the $10 \%$ level; ** Significant at the 5\% level; *** Significant at the $1 \%$ level. Regional, legal origin, and data source dummies were also included. White-heteroskedasticity-corrected standard errors are within parenthesis.

used as the dependent variables. This evidences the value added of splitting total R\&D in its two components. Results for private and public R\&D are in Tables 3 and 4, respectively. Leave aside for a moment the ones for the non-22-OECD sample (columns 5 to 6) that are distinctly different. As with total R\&D, population, the government share, and relative TFP are strong positive determinants of private and public R\&D, and TFP growth shows no power. Interestingly, when GDP is incorporated (columns 2 and 4) into the model, relative TFP looses its power to explain public R\&D (it maintains though some weak power in the S\&T sample) but not to explain private R\&D. In addition, GDP is significant in the public effort regression but not in the private one. This is consistent with Wagner's law.

Schooling, private credit, and the patent index in columns (1) and (3), Tables 3 and 4, have positive signs when they are significant, but show clearly more power to explain private R\&D than public innovation effort. When GDP is included (columns 2 and 4), these explanatory variables remain important for private $R \& D$, but not for public R\&D. The exception in this case is credit with public R\&D (column 2, Table 4) that becomes weakly signifi- 
cant with a negative sign.

Table 3 - Regression results for the private R\&D share in GDP

\begin{tabular}{|c|c|c|c|c|c|c|}
\hline \multirow{2}{*}{ Variables } & \multicolumn{2}{|c|}{ Whole sample } & \multicolumn{2}{|c|}{ S\&T group } & \multicolumn{2}{|c|}{ Excluding 22-OECD } \\
\hline & (1) & (2) & (3) & (4) & (5) & (6) \\
\hline \multirow[t]{2}{*}{$\ln (\mathrm{Popu})$} & $0.147^{* * *}$ & $0.146 * * *$ & $0.211^{* * *}$ & $0.209 * * *$ & -0.122 & -0.201 \\
\hline & $(0.054)$ & $(0.054)$ & $(0.057)$ & $(0.056)$ & $(0.105)$ & $(0.119)$ \\
\hline \multirow[t]{2}{*}{ In(School) } & $1.075^{* * *}$ & $1.115^{* * *}$ & $0.682^{* * *}$ & $0.707 * * *$ & -0.878 & $-1.726 * * *$ \\
\hline & $(0.310)$ & $(0.314)$ & $(0.253)$ & $(0.249)$ & $(0.586)$ & $(0.620)$ \\
\hline \multirow[t]{2}{*}{ Open } & $0.001^{*}$ & $0.001^{*}$ & $0.002 * * *$ & $0.003 * * *$ & $0.004 * * *$ & $0.003 * *$ \\
\hline & $(0.001)$ & $(0.001)$ & $(0.001)$ & $(0.001)$ & $(0.001)$ & (o.ol) \\
\hline \multirow[t]{2}{*}{ Poli. Rights } & 0.008 & 0.005 & $-0.100 *$ & $-0.103 *$ & -0.025 & -0.015 \\
\hline & $(0.040)$ & $(0.041)$ & $(0.059)$ & $(0.060)$ & $(0.037)$ & $(0.035)$ \\
\hline \multirow[t]{2}{*}{ Gov.Sr. } & $0.018 * * *$ & $0.018^{* * *}$ & $0.013 * *$ & $0.013 * *$ & $0.047 * * *$ & $0.058 * * *$ \\
\hline & $(0.004)$ & $(0.005)$ & $(0.006)$ & $(0.006)$ & (0.009) & $(0.011)$ \\
\hline \multirow[t]{2}{*}{$\ln (R G D P p)$} & --- & -0.222 & --- & -0.262 & --- & $1.193^{* * *}$ \\
\hline & & $(0.366)$ & & $(0.272)$ & & $(0.419)$ \\
\hline \multirow[t]{2}{*}{ Credit } & $0.122 * *$ & $0.141 * *$ & $0.097 * *$ & $0.114 * *$ & $0.328^{*}$ & 0.202 \\
\hline & $(0.053)$ & $(0.063)$ & $(0.046)$ & $(0.049)$ & (0.189) & $(0.146)$ \\
\hline \multirow[t]{2}{*}{ In(Patent I.) } & $0.707 * * *$ & $0.755^{* * *}$ & $0.682 * * *$ & $0.774 * * *$ & 0.301 & 0.230 \\
\hline & $(0.281)$ & $(0.301)$ & $(0.254)$ & $(0.252)$ & $(0.268)$ & $(0.297)$ \\
\hline \multirow[t]{2}{*}{$\ln ($ Re.TFP) } & $0.980 * * *$ & $1.217^{* * *}$ & $0.753 * *$ & $1.031 * *$ & $0.933 * *$ & -0.357 \\
\hline & $(0.267)$ & $(0.403)$ & $(0.367)$ & $(0.469)$ & $(0.388)$ & $(0.568)$ \\
\hline \multirow[t]{2}{*}{ TFP growth } & 0.017 & 0.018 & -0.002 & -0.001 & -0.019 & -0.025 \\
\hline & $(0.014)$ & $(0.014)$ & $(0.015)$ & $(0.015)$ & $(0.027)$ & $(0.024)$ \\
\hline Observ. & 119 & 119 & 94 & 94 & 36 & 36 \\
\hline $\mathrm{R}^{2}$ & 0.831 & 0.832 & 0.846 & 0.847 & 0.889 & 0.909 \\
\hline $\bar{R}^{2}$ & 0.805 & 0.804 & 0.816 & 0.815 & 0.805 & 0.831 \\
\hline
\end{tabular}

Notes: * Significant at the $10 \%$ level; ** Significant at the $5 \%$ level; *** Significant at the $1 \%$ level. Regional, legal origin, and data source dummies were also included. White-heteroskedasticity-corrected standard errors are within parenthesis.

Political rights and openness have different effects on both R\&D components. On the one hand, openness affects positively private $R \& D$, but has a negative non-significant impact on public R\&D. Political rights, on the other, depicts in the S\&T sample (columns 3 and 4), where rich nations dominate at a larger extent, two opposing significant effects: weak and positive (negative sign) for private R\&D and strong and negative (positive sign) for the its public counterpart.

Summarizing, we could say that results for the whole sample and the S\&T group describe some interesting patterns. Three of our market-failure proxies - access to credit, patent protection, and relative TFP - show stronger power to predict private R\&D. The fourth one, TFP growth, has no power. The political-pressure proxy government size shows strong positive power to explain both R\&D variables, and openness and political rights have opposing effects on them.

Focusing next on the non-22-OECD nations, some of these patterns do not hold: market-failure variables do not seem to be more important to pre- 
Table 4 - egression results for the public R\&D share in GDP

\begin{tabular}{|c|c|c|c|c|c|c|}
\hline \multirow{2}{*}{ Variables } & \multicolumn{2}{|c|}{ Whole sample } & \multicolumn{2}{|c|}{ S\&T group } & \multicolumn{2}{|c|}{ Excluding 22-OECD } \\
\hline & (1) & (2) & (3) & (4) & (5) & (6) \\
\hline \multirow[t]{2}{*}{$\ln (\mathrm{Popu})$} & $0.177^{* * *}$ & $0.178 * * *$ & $0.055^{*}$ & $0.063 * *$ & 0.132 & 0.002 \\
\hline & $(0.040)$ & $(0.039)$ & $(0.032)$ & $(0.030)$ & $(0.142)$ & $(0.088)$ \\
\hline \multirow[t]{2}{*}{ In(School) } & $0.380 *$ & 0.269 & $0.393^{*}$ & 0.319 & $-1.188 *$ & $-2.577 * * *$ \\
\hline & $(0.207)$ & $(0.201)$ & $(0.205)$ & $(0.200)$ & $(0.628)$ & (0.517) \\
\hline \multirow[t]{2}{*}{ Open } & 0.000 & 0.000 & -0.001 & $-0.001 *$ & 0.002 & 0.001 \\
\hline & $(0.001)$ & $(0.001)$ & $(0.001)$ & $(0.001)$ & $(0.001)$ & $(0.001)$ \\
\hline \multirow[t]{2}{*}{ Poli. Rights } & 0.030 & 0.040 & $0.155^{* * *}$ & $0.164 * * *$ & -0.037 & -0.021 \\
\hline & $(0.027)$ & $(0.025)$ & $(0.045)$ & $(0.041)$ & $(0.030)$ & $(0.024)$ \\
\hline \multirow[t]{2}{*}{ Gov.Sr. } & $0.017 * * *$ & $0.020 * * *$ & $0.019 * * *$ & $0.021 * * *$ & $0.026 * * *$ & $0.045^{* * *}$ \\
\hline & $(0.003)$ & $(0.003)$ & $(0.003)$ & $(0.003)$ & $(0.008)$ & $(0.007)$ \\
\hline \multirow[t]{2}{*}{$\ln (R G D P p)$} & --- & $0.624^{* *}$ & --- & $0.779 * * *$ & --- & $1.954 * * *$ \\
\hline & & $(0.263)$ & & (0.159) & & (0.398) \\
\hline \multirow[t]{2}{*}{ Credit } & -0.016 & $-0.069 *$ & $0.065 * *$ & 0.013 & -0.182 & $-0.389 * * *$ \\
\hline & $(0.036)$ & $(0.039)$ & $(0.031)$ & $(0.027)$ & $(0.138)$ & (0.104) \\
\hline \multirow[t]{2}{*}{ In(Patent I.) } & 0.001 & -0.134 & $0.270^{*}$ & -0.005 & -0.136 & -0.251 \\
\hline & $(0.187)$ & $(0.200)$ & $(0.148)$ & (0.139) & $(0.272)$ & $(0.307)$ \\
\hline \multirow[t]{2}{*}{$\ln ($ Re.TFP) } & $0.715^{* * *}$ & 0.050 & $1.389 * * *$ & $0.559 *$ & $1.285^{* * *}$ & -0.828 \\
\hline & $(0.184)$ & $(0.358)$ & $(0.246)$ & $(0.302)$ & $(0.476)$ & $(0.529)$ \\
\hline \multirow[t]{2}{*}{ TFP growth } & 0.013 & 0.011 & 0.004 & 0.003 & $0.035^{*}$ & $0.023^{*}$ \\
\hline & $(0.011)$ & $(0.011)$ & $(0.010)$ & (0.009) & (0.019) & $(0.014)$ \\
\hline Observ. & 119 & 119 & 94 & 94 & 36 & 36 \\
\hline $\mathrm{R}^{2}$ & 0.695 & 0.713 & 0.732 & 0.770 & 0.707 & 0.848 \\
\hline $\bar{R}^{2}$ & 0.647 & 0.665 & 0.681 & 0.722 & 0.488 & 0.720 \\
\hline
\end{tabular}

Notes: * Significant at the $10 \%$ level; ** Significant at the $5 \%$ level; ${ }^{* * *}$ Significant at the $1 \%$ level. Regional, legal origin, and data source dummies were also included. White-heteroskedasticity-corrected standard errors are within parenthesis.

dict private effort, and political rights and openness do not deliver opposite effects on the two R\&D components. In particular, Table 3, columns (5) and (6), implies that private R\&D is positively associated with the degree of openness, government spending, credit, and relative TFP. The significance of the coefficients associated with the last two variables, however, disappears once GDP joins the regressor set; in column (6), private R\&D is explained by openness, the government share, and the level of GDP, all with positive signs. Schooling appears also significant but with a negative sign that makes it difficult to interpret. Results with public R\&D are similar, the size of government and the level of GDP represent its strongest predictors, and show a positive relation. When GDP is in the regression, credit also matters negatively to explain public R\&D effort.

Results are different depending on whether or not GDP is included in the regression. To assess which ones are more supported by the data, we can employ the corrected R-squared given in the last row of each table. In Table $3, \bar{R}^{2}$ is slightly higher when GDP is not included (columns 1 and 3) than when it is (columns 2 and 4) with the whole sample and the S\&T group. 
The statistic $\bar{R}^{2}$ is, however, significantly higher when GDP is present in the non-22-OECD sample. In particular, including GDP, the corrected R-square increases from 0.805 to 0.831 . For public expenditure in R\&D, Table $4, \bar{R}^{2}$ is always substantially larger when GDP is used as an additional regressor.

\section{Conclusions}

This paper searches for the determinants of private and governmentfunded R\&D. Its main goal has been to disentangle whether the marketfailure considerations emphasized by the theoretical literature are the main driving forces behind public R\&D expenditures. Another goal of the paper has been to find out whether other types of R\&D policy such as patent protection can have an impact on private $R \& D$.

The paper finds that private and government $R \& D$ are, in general, driven by different forces, and that these forces vary between country groups as well. Focusing first on the whole, and the high- and middle-income samples, results imply that private $R \& D$ responds to efficiency considerations as expected, whereas public R\&D mainly to political factors. Market size approximated by population, labor-force schooling levels, the degree of openness, private credit to the private sector, the distance to the technology frontier, and the patent protection levels predict well private innovation expenditures, and their impact is positive.

Government spending and political rights also affect positively private R\&D in the set of rich and middle income economies. This can imply that the government supplies services that increase the productivity of the private $R \& D$ sector, like effective legal protection and basic infrastructure, and that the quality of the service increases with political freedom in those economies. These effects parallel the ones obtained by previous literature for total R\&D investment, with the exception of openness: I find that when you restrict attention to private R\&D or to high and middle income nations, openness matters. Importantly, once other variables are kept constant, GDP has no impact on private $R \& D$.

Public R\&D, on the other hand, is positively determined by GDP per capita levels, population, and also by the government share in GDP. The first two factors imply that $R \& D$ expenditure carried out by government can be associated with the perceived additional needs for government services brought about by the process of industrialization and urbanization, as the Wagner's hypothesis suggests. Its relationship with government size, in turn, suggests that public R\&D varies with the capacity of government to mobilize resources. Political rights also have a strong impact on public effort, but this effect is negative, that is, the opposite to what Meltzer and Richard's (1981) insight suggests. The effect of political rights on public $R \& D$ is then not driven by redistributed forces. Finally, openness shows a weak negative association with public R\&D, suggesting that budgetary 
pressure might be having an effect.

This does not mean that public R\&D is exclusively determined by political considerations. The data find some weak support for the influence of the distance to the technology frontier for developed and middle income nations. As economies get closer to the frontier, there seems to be additional public support. The lesson is that political factors in rich nations play a much more important role.

Turning now to developing economies, results go towards the other direction, and suggest that market-failure considerations have a larger weight in public innovation effort. Along with the size of government and GDP per capita, the lack of private credit and knowledge-spillover effects are positively related to public R\&D. The fact that, in this country group, schooling shows a negative sign may mean that governments try to fight against the lack of formal education through investment in R\&D that should help to educate new scientists.

In light of the results, $R \& D$ policy is effective at promoting $R \& D$ investment. However, the types of policy measures that are effective can differ across countries. Measures directed to improving credit access, patent protection, and getting closer to the technology frontier fosters private R\&D in rich nations, but are not a driving force in developing countries. In these last economies, private $R \& D$ responds mainly to public efforts, which most likely help to build the base of knowledge, human and physical capital necessary for successful R\&D.

Evidence then suggests that governments do not implement optimal policies, but rather second-best ones due to political distortions. This has some important implications. Possibly, the main one is that more research on political economy theories of innovation is essential to understand and improve R\&D policy. From the point of view of policymakers, the lesson is that direct $R \& D$ interventions need to be reassessed to make it closer to efficiency considerations. In addition, results warn that the standard argument that a country's government should spend more in R\&D just because other countries spend a relatively higher share of GDP in R\&D is not well founded, because politics and not efficiency is the dominant force. Further research is necessary to address these and other important related issues. 


\section{References}

Acemoglu, D., Linn, J., 2004. Market Size in Innovation: Theory and Evidence from the Pharmaceutical Industry. Quarterly Journal of Economics 119, 1049-1090. doi:10.1162/0033553041502144

Aghion, P., Howitt, P., 1992. A Model of Growth through Creative Destruction. Econometrica, 60, 323-351. doi:10.2307/2951599

Aghion, P., Howitt, P., 2006. Appropriate Growth Policy: A Unifying Framework. Journal of the European Economic Association 4, 269-314. doi: 10.1162/jeea.2006.4.2-3.269

Aghion, P., Bloom, N., Blundell, R., Griffith, R., Howitt, P., 2005. Competition and Innovation: An Inverted-U Relationship. Quarterly Journal of Economics 120, 701-728. doi:10.1093/qje/120.2.701

Arrow, K.J., 1962. Economic Welfare and the Allocation of Resources for Invention. In: Nelson, R. (Ed.), The Rate and Direction of Inventive Activity. Princeton University Press, Princeton, NJ, pp. 609-625.

Avelino, G., Brown, D.S., Hunter, W., 2005. The Effects of Capital Mobility, Trade Openness, and Democracy on Social Spending in Latin America, 1980-1999. American Journal of Political Science 49, 625-641. doi:10.1111/j.1540-5907.2005.00146.x

Barro, R.J., Lee, J.W., 2001. International Data on Educational Attainment: Updates and Implications. Oxford Economic Papers 53, 541-563. doi:10.1093/oep/53.3.541

Barro, R.J., Sala-i-Martin, X., 1995. Economic Growth. McGraw-Hill, New York.

Barro, R.J., Sala-i-Martin, X., 1997. Technological diffusion, convergence, and growth. Journal of Economic Growth 2, 1-26. doi:10.1023/A:1009746629269

Beck, T., Demirgüç-Kunt, A., Levine, R., 2000. A New Database on Financial Development and Structure. World Bank Economic Review 14, 597-605. doi:10.1093/wber/14.3.597

Coe, D.T., Helpman, E., 1995. International R\&D Spillovers. European Economic Review 39, 859-887. doi:10.1016/0014-2921(94)00100-E

David, P.A., Hall, B.H., Toole, A.A., 2000. Is Public R\&D a Complement or Substitute for Private R\&D? A Review of the Econometric Evidence. Research Policy 29, 497-529. doi:10.1016/S0048-7333(99)00087-6 
Drazen, A., 2000. Political Economy in Macroeconomics. Princeton University Press, Princeton, NJ.

Dreher, A., Sturm, J.E., Ursprung, H., 2008. The Impact of Globalization on the Composition of Government Expenditures: Evidence from Panel Data. Public Choice 134, 263-292. doi:10.1007/s11127-007-9223-4

Easterly, W., Rebelo, S., 1993. Fiscal Policy and Economic Growth: An Empirical Investigation. Journal of Monetary Economics 32, 417-458. doi:10.1016/0304-3932(93)90025-B

Eaton, J., Kortum, S., 1996. Trade in Ideas: Patenting and Productivity in the OECD. Journal of International Economics 40, 251-278. doi:10.1016/00221996(95)01407-1

Fagerberg, J., 1988. International Competitiveness. Economic Journal 98, 355- 374. doi:10.2307/2233372

Gallup, J.L., Sachs, J.D., Mellinger, A.D., 1999. Geography and Economic Development. In Pleskovic, B., Stiglitz, J.E. (Eds.), World Bank Annual Conference on Development Economics 1998. World Bank, Washington. doi:10.1596/0-8213-4321-1

Ginarte, J.C., Park, W.G., 1997. Determinants of Patents Rights: A Cross-national Study. Research Policy 26, 283-301. doi:10.1016/S00487333(97)00022-X

Griliches, Z., 1992. The Search for R\&D Slillovers. Scandinavian Journal of Economics 94, 29-47. doi:10.2307/3440244

Hall, B.H., 2005. The Financing of Innovation. In: Shane, S. (Ed.), Handbook of Technology Management, Blackwell Publishers, Oxford, U.K..

Howitt, P., 1999. Steady-State Output Growth with Population and R\&D Inputs Growing. Journal of Political Economy 107, 715-730. doi: $10.1086 / 250076$

Howitt, P., 2004. Endogenous Growth, Productivity and Economic Policy: A Progress Report. International Productivity Monitor 8, 3-15.

Jones, C.I., 1995. RD-Based Models of Economic Growth. Journal of Political Economy 103, 759-84. doi:10.1086/262002

Jones, C.I., Williams, J.C., 1998. Measuring the Social Return to R\&D. Quarterly Journal of Economics 113, 1119-1135. doi:10.1162/003355398555856

Jones, C.I., Williams, J.C., 2000. Too Much of a Good Thing? The Economics of Investment in R\&D. Journal of Economic Growth 5, 65-85. doi:10.1023/A:1009826304308 
La Porta, R., Lopez-de-Silanes, F., Shleifer, A., 2008. The Economic Consequences of Legal Origins. Journal of Economic Literature 46, 285-332. doi:10.1257/jel.46.2.285

La Porta, R., Lopez-de-Silanes, F., Shleifer, A., Vishny, R., 1999. The Quality of Government. Journal of Law and Economic Organization 15, 222-279. doi:10.1093/jleo/15.1.222

Lederman, D., Maloney, W.F., 2003. R\&D and Development. World Bank Policy Research Working Paper 3024.

Mankiw, G., Romer, D., Weil, D.N., 1992. A Contribution to the Empirics of Economic Growth. Quarterly Journal of Economics 107, 407-437. doi:10.2307/2118477

Meltzer, A.H., Richard, S.F., 1981. A Rational Theory of the Size of Government. Journal of Political Economy 89, 914-927. doi:10.1086/261013

Nelson, R.R., 1959. The Simple Economics of Basic Scientific Research. Journal of Political Economy 67, 297-306. doi:10.1086/258177

Parente, S.L., Prescott., E.C., 1994. Barriers to Technology Adoption and Development. Journal of Political Economy 102, 298-321. doi:10.1086/261933

Park, W.G., 2008. International Patent Protection: 1960-2005. Research Policy 37, 761-766. doi:10.1016/j.respol.2008.01.006

Rivera-Batiz, L., Romer, P.M., 1991. Economic Integration and Endogenous Growth. Quarterly Journal of Economics 106, 531-55. doi:10.2307/2937946

Romer, P.M., 1990. Endogenous Technological Change. Journal of Political Economy 98, S71-S102. doi:10.1086/261725

Schulze, G., Ursprung, H., 1999. Globalization of the Economy and the Nation State. World Economy 22, 295-352. doi:10.1111/1467-9701.00205

Schumpeter, J.A., 1942. Capitalism, Socialism and Democracy, Harper and Brothers, New York.

Solow, R., 1956. A Contribution to the Theory of Economic Growth. Quarterly Journal of Economics 70, 65-94. doi:10.2307/1884513

Solow, R., 1957. Technical Change and the Aggregate Production Function. Review of Economics and Statistics 39, 312-320. doi:10.2307/1926047

Solow, R., 1962. Technical Progress, Capital Formation, and Economic Growth. American Economic Review 52, 76-86. 
Varsakelis, N.C., 2001. The Impact of Patent Protection, Economy Openness and National Culture on R\&D Investment: A Cross-Country Empirical Investigation. Research Policy 30, 1059-1068. doi:10.1016/S00487333(00)00130-X

Varsakelis, N.C., 2006. Education, Political Institutions and Innovative Activity: A Cross-Country Empirical Investigation. Research Policy 35, 10831090. doi:10.1016/j.respol.2006.06.002

Wagner, A., 1967. Three Abstracts on Public Finance. In Musgrave, R.A., Peacock, A.T. (Eds.), Classics in Theory of Public Finance. St Martins Press, New York. 


\section{Appendix}

First, we state the central planner's problem. Let $C$ and $K$ be the amounts of aggregate consumption and the country stock of physical capital, respectively. The capital stock is the sum of all producer durables units, $K=$ $\int_{0}^{A} x_{i} d i$. A central planner would choose the time paths $\left\{K(t), R_{C}(t), R_{I}(t), C(t)\right\}_{t=0}^{\infty}$ so as to maximize the lifetime utility of the representative consumer subject to the feasibility constraints of the economy. The problem can be stated as follows:

$$
\max _{\left\{C, R_{I}, R_{C},\right\}} \int_{0}^{\infty}\left[\frac{\left(\frac{C}{L}\right)^{1-\sigma}-1}{1-\sigma}\right] e^{-\rho t} d t
$$

subject to

$$
\begin{gathered}
Y=A^{\xi} L^{\alpha} K^{1-\alpha} \\
\dot{K}=Y-C-R_{I}-R_{C} \\
\dot{A}=\mu A^{\phi}\left[R_{I}^{\lambda}+\left(\frac{A^{w}}{A}\right)^{\beta} R_{C}^{\lambda}\right] \\
\frac{\dot{A}^{w}}{A^{w}}=g_{A^{w}} \\
\frac{\dot{L}}{L}=n
\end{gathered}
$$

where $\rho$ is the discount factor; and $\xi$ equals $\frac{1}{\gamma}-(1-\alpha)$. Equation $(7)$ is the well known Cobb-Douglas form in which production function (1) takes at the aggregate level. $Y$ can be interpreted as the Gross Domestic Product of the economy. Expression (8) is the economy's budget constraint as well as the law of motion of the capital stock.

Setting up the usual Hamiltonian and solving this program yields the optimal paths. The FOC with respect to aggregate consumption gives

$$
\left(\frac{\dot{C}}{C}-n\right) \sigma=r-\rho-n ;
$$

where $r$ is the interest rate, and equals the return to capital investment,

$$
r=(1-\alpha) A_{t}^{\xi} L_{t}^{\alpha} K_{t}^{-\alpha}-\delta
$$

The concavity of the production and $R \& D$ technologies guarantees that output will be distributed evenly over all activities. Both innovation and imitation will coexist in equilibrium as long as the pool of ideas that can be 
copied is not empty. The FOCs with respect to the two R\&D activities imply that the socially optimal ratio of imitation to innovation is

$$
\frac{R_{C}}{R_{I}}=\left(\frac{A^{w}}{A}\right)^{\beta /(1-\lambda)} .
$$

As the economy catches up with the technology frontier, imitation becomes relatively less productive, increasing the share of $R \& D$ investment that goes to invent new types of producer durables.

Let $R$ be the total amount of resources invested in R\&D; that is, the sum of $R_{C}$ and $R_{I}$. From (14) and (2), we can write the motion equations of the technology level and the capital stock as follows:

$$
\begin{gathered}
\dot{A}=\mu A^{\phi} R^{\lambda}\left[1+\left(\frac{A^{w}}{A}\right)^{\beta /(1-\lambda)}\right]^{1-\lambda} \\
\dot{K}=Y-C-R-\delta K .
\end{gathered}
$$

Using (14) and the FOC with respect to either innovation or imitation effort, we obtain the Euler equation that governs the dynamics of the optimal R\&D investment,

$$
r=\lambda \frac{\dot{A}}{A}\left(\frac{\xi Y}{R}\right)+\frac{\dot{A}}{A}\left(\phi-\beta \frac{\left(A^{w} / A\right)^{\beta /(1-\lambda)}}{1+\left(A^{w} / A\right)^{\beta /(1-\lambda)}}\right)+\left(\frac{\dot{R}}{R}-\frac{\frac{d \dot{A}}{d t}}{\dot{A}}\right)
$$

It can be interpreted as an arbitrage condition. At the optimum, the central planner must be indifferent between investing one additional unit of output in R\&D and investing it in intermediate goods production.

The system of differential equations composed of Euler conditions (12) and $(17)$, the laws of motion $(10),(11),(15)$ and $(16)$, along with the usual initial and transversality conditions characterize the equilibrium allocations in the model.

Next, we restrict our attention to the perfect-foresight equilibrium balanced growth path in which the growth rates of all variables in the model are constant. Let $x^{*}$ and $g_{x}$ denote the optimal allocation and the growth rate of variable $x$ along the balanced growth path, respectively. From the capital accumulation equation (2), we must have $g_{Y}=g_{C}=g_{R_{I}}=g_{R_{C}}=g_{K}$. From R\&D technology (8) in turn, we see immediately that because $g_{R_{I}}=g_{R_{C}}$, it must be true that $g_{A} w=g_{A}$, otherwise $g_{A}$ cannot be constant. The value of $A^{w} / A$ then remains invariant along the balanced growth path.

From Jones (1995), we know that the steady state growth rate of per capita output and the interest rate are exogenous, exclusively pinned down by the production and $\mathrm{R} \& \mathrm{D}$ technologies. Because $A^{w} / A$ is a constant along the balanced growth path, equation (15) implies that

$$
(\phi-1) g_{A}+\lambda g_{R}=0 \text {. }
$$


From expression (13), we also deduce that

$$
\xi g_{A}+\alpha n-\alpha g_{K}=0 .
$$

The last two equalities, and the fact that $g_{Y}=g_{K}=g_{R}$ say that

$$
g_{Y}=\frac{\alpha n}{\alpha-\frac{\xi \lambda}{1-\phi}} .
$$

Condition (17) evaluated at the steady state delivers the share of output going to R\&D along the balanced growth path

$$
S_{R}^{s p}=\frac{R}{Y}=\frac{\lambda \xi g_{A}}{r^{*}-\left(g_{Y}-g_{A}\right)-g_{A}\left[\phi-\beta \frac{\left(A^{w} / A\right)^{\beta / 1-\lambda}}{1+\left(A^{w} / A\right)^{\beta / 1-\lambda}}\right]} .
$$

Let us turn now to the decentralized equilibrium. Inputs must be exclusively supplied to domestic firms. At each date, consumers supply their labor inelastically. In return for this service, they receive a wage $w$. We assume the existence of a capital market that supplies the savings of consumers to intermediate-goods producers that issue securities. The equilibrium interest rate $r$ clears the market at each point in time. The representative consumer's feasibility constraint is then given by

$$
\dot{a}=(r-n) a+w-c ;
$$

where $a$ is the value, in terms of output, of the securities owned by each consumer.

The infinitely-lived consumer chooses the time series of consumption $(c=C / L)$ that maximizes (6) subject to (22). The first order condition to this problem gives the Euler equation for aggregate consumption:

$$
\frac{\dot{c}}{c}=\frac{1}{\sigma}(r-\rho-n) .
$$

Final-goods manufacturers are price takers, and earn zero profits in equilibrium. Because intermediate goods are rented rather than sold, equation (1) implies that they solve the following problem:

$$
\max _{\left\{L, x_{i}\right\}}\left\{L^{\alpha}\left[\int_{0}^{A} x_{i}^{(1-\alpha) \gamma} d i\right]^{\frac{1}{\gamma}}-\omega L-\int_{0}^{A} p_{i} x_{i} d i\right\} ;
$$

where $\omega$ is the wage rate; and $p_{i}$ the rental price of variety $i$. For the interior solution to this problem, the first order conditions are

$$
\omega=\alpha \frac{Y}{L}
$$




$$
p_{i}=(1-\alpha) L^{\alpha}\left[\int_{0}^{A} x_{j}^{(1-\alpha) \gamma} d j\right]^{\frac{1}{\gamma}-1} x_{i}^{(1-\alpha) \gamma-1}, \quad i \in(0, A) .
$$

Equations (25) and (26) represent the inverse demand functions for labor and producer durables, respectively. Given that all intermediate-goods designs provide the same improvement in productivity, we hereafter focus on the symmetric equilibrium in which capital is evenly distributed over all available types; that is, $x_{i}=\bar{x}$ for all $i$.

Intermediate-goods manufacturers borrow capital that is allocated to producing existing varieties of producer durables and to R\&D. Assume that one unit of raw capital can be costlessly converted into one unit of any type of producer durable, and that intermediate goods are rented rather than sold and do not depreciate. Intermediate-goods producers act as monopolists, taking the final-output manufacturers' inverse demand function as given. The solution to their problem is well known: monopolists charge a markup over marginal cost; and in the symmetric equilibrium, assuming that the number of firms is large, the markup equals the inverse of the elasticity of substitution between intermediate goods. The rental price of variety $i$ is then given by

$$
p_{i}=\frac{r}{\gamma(1-\alpha)}=\bar{p}, \text { for all } i \text {. }
$$

Equations (26) and (27) then imply that the amount of producer durables of a given type used in the economy is

$$
\bar{x}=\frac{(1-\alpha)^{2} \gamma}{r}\left(\frac{Y}{A}\right) .
$$

We now determine the competitive equilibrium allocation to $R \& D$. The R\&D technology in given by expression (2). Free entry in the producerdurables sector implies that, at each instant in time, the amount invested in learning must equal the present value of the ideas. We will then have two zero-profit equilibrium conditions, one for innovation and another for imitation. They can be stated formally as follows:

$$
R_{I}=V \mu A^{\phi} R_{I}^{\lambda}
$$

and

$$
R_{C}=V \mu A^{\phi}\left[R_{C}\left(\frac{A^{w}}{A}\right)^{\beta}\right]^{\lambda} ;
$$

where $V$ is the present value of any patent right at a given date - notice that all designs are alike in productivity terms, regardless of whether they are copied or created from scratch. Combining expressions (29) and (30), we obtain the optimal ratio of imitation to innovation investment in the competitive equilibrium with taxes:

$$
\frac{R_{C}}{R_{I}}=\left(\frac{A^{w}}{A}\right)^{\beta \lambda /(1-\lambda)}
$$


Knowing the gains from discovering new designs, intermediate-goods producers choose how much capital to invest in R\&D. Let $R=R_{C}+R_{I}$. From equations (29), (30) and (31), we can write the zero profit condition for total R\&D effort as

$$
R^{1-\lambda}=V \mu A^{\phi}\left[1+\left(\frac{A_{t}^{w}}{A_{t}}\right)^{\frac{\beta}{1-\lambda}}\right]^{1-\lambda} .
$$

The firms' optimal allocation to R\&D across time will be determined by the evolution of the design's value $V_{t}$, which is pinned down by the following arbitrage condition:

$$
r V=(\bar{p}-r) \bar{x}+\left(\dot{V}-\psi \frac{\dot{A}}{A} V\right) ;
$$

The RHS represents the return to engaging in intermediate-goods manufacturing. Buying a patent right today and manufacturing the products that will be rented tomorrow provides a return that equals the dividend (first summand) plus the capital gain/loss (term in parenthesis) that takes into the probability that an existing design is replaced by an upgrade. The LHS, in turn, gives the return from lending to other firms. The above expression says that, in equilibrium, firms must be indifferent between the two alternatives.

Expressions (18) and (32) imply that along the balanced growth path

$$
\frac{\dot{V}}{V}=g_{Y}-g_{A} .
$$

This equation along with (27), (28) and (33) imply that

$$
V=\frac{[1-\gamma(1-\alpha)](1-\alpha) \frac{Y}{A}}{r^{*}-\left(g_{Y}-g_{A}\right)+\psi g_{A}} \text {. }
$$

Now, from (29) and (30), we can write

$$
R=V(1+\psi) \dot{A}
$$

The last two expressions deliver the steady-state share of $R \& D$ in the decentralized economy as

$$
S_{R}^{d e}=\frac{[1-\gamma(1-\alpha)](1-\alpha)(1+\psi) g_{A}}{r^{*}-\left(g_{Y}-g_{A}\right)+\psi g_{A}} .
$$

Noting that $\eta=1 /[\gamma(1-\alpha)]$, we obtain (4). 